\title{
The Contributing Factors of General Adjustment On Malaysian Expatriates In Construction Industry Overseas
}

\author{
${ }^{1}$ Halmi Zainol, ${ }^{2}$ Haryati Mohd Isa, ${ }^{3}$ Kartina Alauddin and ${ }^{4}$ Mohmad Mohd Derus \\ ${ }^{1}$ Assoc. Prof., Dr :Town and Regional Planning Department, Faculty of Architecture, Planning and Surveying, \\ Universiti Teknologi MARA, Seri Iskandar Campus \\ ${ }^{2,3,4} \mathrm{Dr}$ : Quantity Surveying Department, Faculty of Architecture, Planning and Surveying, \\ Universiti Teknologi MARA, Seri Iskandar Campus \\ halmi461@perak.uitm.edu.my, harya966@ perak.uitm.edu.my, karti540@ perak.uitm.edu.my, \\ moham266@perak.uitm.edu.my
}

\begin{abstract}
The achievement of Malaysian construction companies create an opportunity to venture abroad. Past reviews have demonstrated that the trouble of expatriates in adjusting to a new environment is the main aspect that leads to the unsuccessful of assignments. The accomplishment in implementing an abroad task does not exclusively rely upon an expatriate's technical expertise. The adjustment issues, for example, the socializing with the local, communication and culture adaptation also influence on the assignment. The study was conducted to identify the contributing factors of general adjustment on assignment faced by Malaysian executive expatriates in host countries. The purpose of the study was to identify adjustment contributing factors relating to general adjustment abroad. Questionnaires were sent to Malaysian expatriate executives. Sixty four Malaysian expatriate executives from Malaysian construction companies abroad were included in this study. The findings indicate interaction, social adaptation and living condition influence their adjustment abroad. A pre-departure training preparation aspect for expatriate is a good measure before their departure to host nations.
\end{abstract}

Keywords : Expatriate, general adjustment, construction, abroad

\section{INTRODUCTION}

The present internationalization of the construction industry demonstrates that Malaysian firms are actively involved in construction projects abroad. The involvement of construction organizations to undertakings projects abroad can greatly establish the position of the organization. In any case, to be successful, an organization must guarantee that individual appointed to work abroad should have the perseverance and must be ever prepared to face challenges. General adjustment refers to the ability of a person to adapt to the new environment. Among the elements that influence the general adjustment are socializing with local, interaction with host nationals, cultural adaptation, communication, living environment and living condition. 
To a great extent, accomplishment of the organizations relies upon the individual assigned to the projects abroad. The effectiveness of the staff assigned depends not only on their specialized capacities, learning, and inventiveness, but also on other non-technical matters that impact the staff in foreign nations. The control over these factors would empower the ideal utilization of employment for guaranteeing accomplishment of an organization (Andreason and Kinneer, 2005; Yang, 2007).

The capacity of the expatriate to adjust to general aspects, jobs, and family influence their performance in their assignments (Anderson, 2001; Katz and Seiffer 1996; Paik, Segaud, and Malinowski, 2002). The diverse environmental conditions in the host nations propose the importance of expatriate of making adjustment so that that they can make the most of their normal life. Not all staff sent abroad can conform themselves to the circumstance abroad. In this manner, to face the new environmental condition in a foreign nation, preparation and adjustment of an expatriate is essential.

Among the purposes behind Malaysian construction organizations getting involved in a foreign nation is to secure market access in the host nation, to build their piece of the overall industry, to reinforce their networking and to pick up new experience (Abdul-Aziz and Wong, 2010a). In 2015, he achievement of a Malaysian construction organization to secure a highway construction, development of smart cities and transit-oriented development in India, opened up opportunities to local Malaysian organizations to invest their resources in foreign construction projects (CIDB, 2016). This shows that foreign acknowledgment towards the capacities of Malaysian construction organizations. Such opportunities have become the foundation for Malaysian organizations to implement foreign projects successfully, apart from expanding their contribution to the national economy. In this association, the requirement for Malaysian expatriate to lead this sort of projects has become a priority.

Malaysian multinational construction organizations are getting projects in foreign nations, for example, in the Southeast Asian region, the Middle East, Asia, Africa and other nations (CIDB, 2009; Zakaria, 2011). Among the issues confronted by expatriate when in foreign nations are that they are unable to adapt to the circumstance of being in another environment and that they are unable to adjust themselves in performing their overwhelming responsibilities abroad (Yang, 2007; Osman-Ghani and Akmal, 2008). Accordingly, the conformity aspects of confronting the circumstance in the host nation ought to be thought about by organizations so that expatriates can have some expectations about the issues they will confront abroad.

Initiatives have been taken by the Construction Industry Development Board (CIDB) to urge local contractors to take an interest in construction projects abroad. The government through CIDB has formed an index of construction organizations involved in construction projects abroad. Furthermore, the government has published the Malaysian Builders Go Global to set up a communication network for the construction industry (CIDB, 2008). With these facilities, Malaysian construction organizations can have direct correspondence with global markets and expand the construction industry in Malaysia, at the same time contributing towards the Malaysian economy. Abdul-Aziz and Wong (2010b) noticed that the involvement of the Malaysian multinational construction organizations abroad was 
with their own initiatives. Nowadays, the Malaysian expatriates are required to work on their subsidiary company abroad based on the needs of their expertise. Most of them are not given any training or description on living environment, foreign local culture and different stratum of society. They face difficulties because of the inability to adapt to the new living and working environment. Therefore, while working abroad, organizations have to offer priority to the necessities of their staff to encourage them in performing out their tasks effectively.

The general adjustment experienced by executive expatriates influences their work fulfillment and persuades them in performing out their assignments (Takeuchi, David, Sophia and Seokhwa, 2007). Expatriates were not just need to perform out their assigned duties well, but also need to face environment changes that require mental quality to acclimate to. Therefore, it is critical to comprehend the progressions they need to face when abroad.

This study focuses on approaches to solve the issues confronted by expatriate in their host nations. The objective of this study is to identify the factors that contribute to the adjustment abroad. In this study, the expatriates are the Malaysian expatriates who have been sent abroad for more than 9 months at a time. They do not include local or third country nationalities engaged by the company abroad. The question that should be answered in this study is that whether there are any non-technical aspects of general adjustment confronted by expatriate of Malaysian multinational construction organizations in their host nations, and what elements these non-technical factors add to the adjustment factors.

\section{EXPATRIATE GENERAL ADJUSTMENT}

General adjustment includes changes in lifestyle, social status, and comfort confronted in the new situation (Black, Mendenhall, and Oddou, 1991; Chi and Chiou, 2007). Life, for every individual is an adjustment process to the current circumstance and making great correspondence with the environment. Andreason and Kinneer (2005) and Selmer and Leung (2007) argued that adjustment to new environment condition influences the psychology of the expatriates in the host nation. In the event that individuals are influenced mentally, for example, in the event that they are feeling uneasiness, sadness, and troubling, when performing out their obligations, it is an indication that they are unable to adjust to the new situation.

Based on the U-curve adjustment theory, expatriates encounter mental changes in the wake of being in a host nation. Pires, Stanton, and Ostenfeld (2006), concur that adjustment is acquired when they have acknowledged and comprehended the progressions that exist in the host nation. At the early stage, the expatriates would not feel the challenges since they are in a phase of "fantasy". However, before long being in the host nation, contrasts begin to surface in the area of their settlement and culture shock (Oberg, 1960; Pires et al., 2006). In any case, the expatriates need to comprehend and acknowledge these distinctions. Yamazaki (2010) found that Japanese expatriates require no less than four years making adjustment. Webb and Wright (1996) likewise said that expatriates from mono culture nations, such as Japan find that it is hard to acclimate to circumstance in different nations that have distinctive cultures. 
General adjustments with respect to nourishment, shopping and banking have also been studied. Webb and Wright (1996) argued that expatriates would confront new things, particularly nourishment when they are in their host nation. Earlier exposures to nourishment in the nation where the expatriates would stay will help them get readied for the progressions that they will confront. Some expatriates frequently go to work in several nations, but then regardless of that they still require this sort of adjustment for their day-to-day comfort (Gregersen and Black, 1992; Hutchings and Ratnasari, 2006). This view is agreed by McGingley (2008) when they concurred that adjustment to nourishment is more urgent compared to health, way of life, and entertainment. As to shopping, Hutchings and Ratnasari (2006) found that shopping is a required day-to-day spending activity for individuals. In addition, there are also differences in the way individuals do shopping in the nation of origin as compared to the host nation. Caligiuri, Lazarova, and Zehetbauer (2004) observed that expatriates need to change in accordance with shopping in light of the fact that in some host nations bargaining is practiced while in their nation of origin this may not be so.

According to Black (1988), the troubles confronted by expatriates to adjust to the expectation for everyday comforts in the host nation would prompt other challenges. Some expatriates who live in a host nation tend to contrast the situation there with that in their nation of origin where it is more pleasant. Hutchings and Ratnasari (2006) concurred with this view. They said that one reason staff reject the offer to work abroad is that the expectation for everyday comforts in the host nation is not quite the same as that of the nation of origin. On the off chance that the expectation for everyday comforts in the host nation is higher than that of their nation of origin, it would be troublesome for the expatriates to adjust to the situation in the host nation (Collings, Scullion and Morley, 2007). Findings by various scholars (e.g. Black and Gregersen, 1999; Huang, Shu-Cheng, and Lawler, 2005; and Okpara and Kabongo, 2011) demonstrated that acclimation to expectations for everyday comforts is emphatically corresponded with conformity of expatriates abroad. This demonstrates that change in accordance with expectations for everyday comforts impacts adjustment of expatriates in their host nations. Huang et al. (2005), Fish (2005), and Bruning and Wang (2006) are among scholars, who has thought about the expectations for everyday comforts adjustment of expatriates.

The interaction with host nation residents is connected to the movement of social activity with the nearby natives of the host nation. This alludes to how agreeable the expatriates connect with nearby natives when they are performing out their undertakings and when they are outside their tasks (Bhaskar-Shrinivas, Harisson, Shaffer, and Luk, 2005; Black, 1988; Chen, 2010; Huang et al., 2005; Shaffer Harrison, Gregersen, Black, and Ferzandi, 2006). Previous expatriates' studies have demonstrated that one fundamental issue of conformity of expatriates is their difficulty to interact with neighbourhood residents during their appointment in the host nation (Black, 1988). Suutari and Riusala (2000) additionally discovered the same issue confronted by expatriates. According to Selmer (2007), in light of the fact that expatriates confront challenges to interact, their adjustment would also take a longer time, thus influences their employment performance. In addition, expatriates need to interact with the environment in order to empower them to take positive actions thus to facilitate their adaptations with local residents (Black and Mendenhall, 1991; Shaffer et al., 2006; Shay and Baack, 2006).

Adaptation to the way of life of the host nation is an adjustment to the social practice and the traditions of the neighbourhood natives in the host nation (Shin, Morgeson, and Campion, 2007). People who can acknowledge the 
distinctions in the host nation will confront less adjustment issues. According to Lewis (1997), it is troublesome for people to acclimate to a situation with a different socio-economy and society. In addition, Black and Mendenhall (1991) and O'Sulivan (2009) argued that dialect is closely identified with culture. Yang (2007) stressed that language is the foundation of culture for a nation. By having great communication with the nearby residents, one demonstrates that he or she is attempting to comprehend and adjust to the neighbourhood culture. This will facilitate social adjustment. Expatriates who have less associations and making less social adjustment to the way of life of the host nation will require a more extended time to make adjustment(Huang et al., 2005).

\section{METHODOLOGY}

This study uses questionnaire to gather information. The population is based on the list of Malaysian construction companies operating in foreign countries, which is obtained from the Construction Industries Development Board (CIDB). A total of 85 Malaysian construction companies were listed by CIDB. However, only 60 construction companies were operating overseas. Questionnaires were distributed to Malaysian expatriates assigned to their various host nations. The questionnaires were sent, attached with a covering letter, through e-mails to the human resource managers which is then to be sent to their executives working abroad. Three follow-up afford were made to obtain their responses (Shay and Baack, 2006). Finally, a total of 64 questionnaires were returned by the respondents. A sampling response rate of $21.1 \%$ was achieved and comparable with the study done by Selmer and Leung (2007) with $20.0 \%$ of response rate. According to Salkind (2006) and Sekaran (2006), 30 respondents is the minimum sample size required for a statistical sample. Data gathered were analysed using Statistical Package for the Social Science programming (SPSS). Data analysis was performed using the quantitative approach as the data obtained were of nominal types. Reliability test were performed using the Cronbach's alpha for determining the reliability of the items tested (Coakes, Steed, and Dzidic; 2006; Piaw, 2006). Factor analysis techniques were performed in light of the interpretation of the research question and findings from statistical analysis (Fish, 2005; Roshana and Ahnuar, 2006). Principal component analysis was used to construct some various variables that were expected to be correlated. It also summarized the data set for data reduction The measurement scale made used of a 5-point Likert scale with $1=$ No adjustment at all to $5=$ Full adjustment (Babbie, 2010; Neuman, 2006). A mean score less than 2.5 represents no adjustment (Abdul Aziz \& Wong, 2010a; Hurme, 2007).

\section{RESULTS AND DISCUSSION}

Based on the sample received, the average age of respondents was 39.3 years old. The age range of respondents was between 24 to 54 years old. It shows that the expatriates were young and energetic. In term of marital status, most of the respondents were married $(84.4 \%)$ and the rest were still single. The position of the respondents was mostly professionals/technical which represents $67.2 \%$, senior management $28.1 \%$ and middle management $4.7 \%$ which was the smallest group.

The general adjustment attribute consists of 13 items, which include socializing with local, interaction with host nationals, culture adaptation, housing condition, and types of local food, shopping, banking, and religious practice. Reliability tests performed on the general dimension obtained the value of $\alpha=.89$. The items with value of 
Cronbach's $\alpha$ greater than 0.7 were selected because acceptable reliability values (Nunnally, 1978; Mackenzie, Podsakoff and Podsakoff, 2011).

Table 1: Factor Analysis for General Adjustment

\begin{tabular}{cccc}
\hline Item & Factor loading & \\
\hline Factor 1 Interaction & & & \\
Socializing with local & .76 & & \\
Interaction with host nationals & .88 & $\alpha=.78$ & $\mathrm{EV}=5.49$ \\
Communication & .87 & \\
Culture adaptation & .75 & \\
\hline
\end{tabular}

Factor 2 Social adaptation

$\begin{array}{cccc}\text { Shopping } & .67 & & \\ \text { Banking } & .72 & \alpha=.78 & \mathrm{EV}=1.52 \\ \text { Cost of living } & .67 & & \\ \text { Entertainment } & .60 & & \\ \text { Healthcare } & .64 & \end{array}$

Factor 3 Living Condition

Living environment $\quad .76$

Housing condition $\quad .84$

.75

KMO Measure of Sampling Adequacy

Barlett's test of Sphericity

Anti-Image Correlation Matrix (MSA)

$.67-.93$

Total Variance

$67.74 \%$

Note: $p<.01 *$. Cronbach's alpha coefficients with values less than 0.7 were deleted.

$$
\mathrm{EV}=\text { Eigenvalue }
$$

Using the Principal Component Analysis (PCA), factor analyses were performed on the 13 items. One item, such as, food suitability was dropped for having communalities value less than .5 . The factor analysis procedure was repeated and returned a Kaiser-Meyer-Olkin (KMO) value of .79 (> .6). The Barlett's test of Sphericity was significant at $p=.00(p<.01)$, and communalities values for all items were greater than .5 (refer to Table 1). The largest eigenvalue was 5.49 for the first factor, followed by 1.52 for the second factor, and 1.12 for the third factor. The first factor obtained the largest eigenvalue because it gave the largest contribution to the changes in the total variance of the changes in the variables (Piaw, 2009). The results from the factor analyses have grouped three factors 
which together explained $67.74 \%$ of the total variance where the first factor explained $45.76 \%$, followed the second factor, which explained $12.65 \%$, and the third factor, which explained $9.33 \%$.

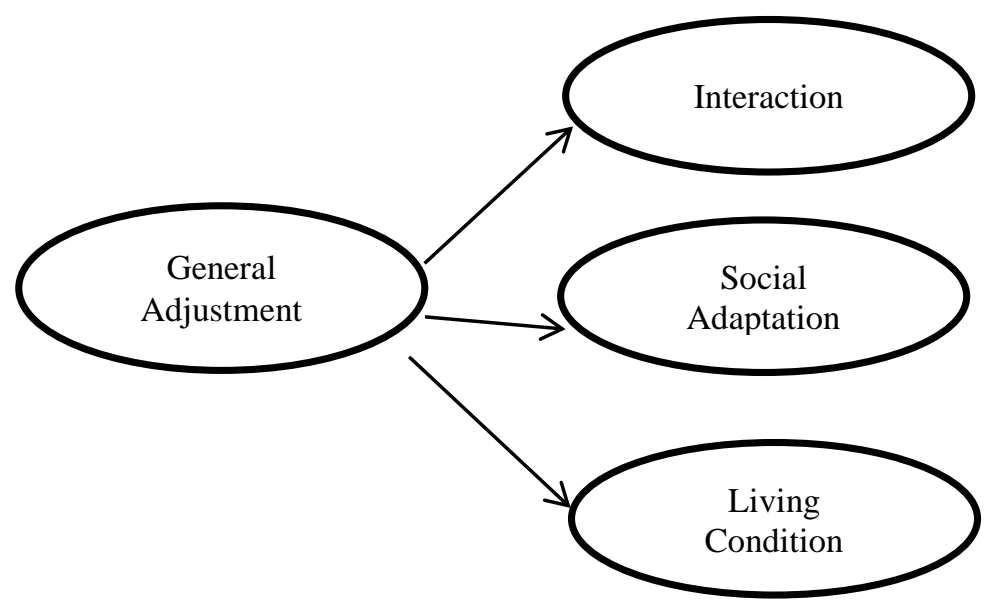

Figure 1: Contributing Factors For General Adjustment

The three factors named interaction, social adaptation, and living condition were found. The interaction adjustment factor comprised items such as socializing with the local society, interaction with local citizens, and adapting to the culture of the host country. The second factor was the social adaptation factor, which include banking, shopping, living standards, recreational and entertainment facilities, and health facilities. The third factor was the living condition, which included living environment, housing condition, and religious practices. After the factors of the items have been identified, reliability tests were performed to determine the reliability of each factor. The Cronbach's alpha reliability test for the general dimension obtained an alpha value for interaction factor $\alpha=.78$, social adaptation $\alpha=.78$, and living condition factor, $\alpha=.89$ Therefore, the reliability of the factors were acceptable.

The results showed that out the 13 items tested, 12 of them were chosen, showing that those items have an influence on the expatriates' general adjustment in confronting the new environment abroad. The item on food adjustment was dropped. This result contradicted the results of previous study done by Black (1988), Webb and Wright (1996), and McGingley (2008). These scholars have included this item on food adjustment. Nevertheless, in the present study, the item was dropped because it did not contribute to factor variance proportion (Field, 2009; Lorio, 2005). From the 12 items, three factors were extracted and named interaction adjustment, social adjustment and living adjustment in accordance with the group of items in the factor.

Four items were grouped under interaction factor. The items were socializing with local society, interacting with local citizens, communication, and adaptation with culture of the host country. These three items were grouped in accordance with Huang et al. (2005) and Lee and Vorst (2010). However, Black (1988) did not include the communication item in his study. This shows that the item socializing with local society, interacting with local 
citizens, communicating and adapting to the culture of the host country is an important aspect which need to be taken into account in expatriates' general adjustment overseas.

With regard to social adaptation, five items were grouped under this factor. This was based on the factor analysis procedure performed. The items extracted were shopping, banking, living standards, recreational and entertainment facilities, and health facilities. Black (1988) has outlined three items that contribute to general adjustment, namely shopping, banking and living standards. However, studies by Pamich (2007) and Toh (2003) have included recreational and entertainment facilities and health facilities under general adjustment. It seems that there is a difference of opinion between the present study and previous studies by Black (1988) and Lee and Vorst (2010) who did not include the aspect of health facilities. The combination of all these items grouped under one factor demonstrates the importance of these items to general adjustment. This is in line with previous analysis and literature which stressed on the comfort of expatriates in adjusting to the living environment abroad (Shay \& Baack, 2006).

Three items were clustered under the living condition factor for general dimension, namely living environment, housing condition, and religious practices. The item living condition and housing condition indicated by Toh (2003), Pamich (2007), and McGingley (2008) are adjustment items that affect adjustment to environment condition. The item religious practices have been considered by Tucker, Bonial and Lahti (2004) and Tahir and Ismail (2007) as having an influence on expatriates' adjustment. However, the present study contradicted this findings.

\section{CONCLUSION}

The study found that three factors, namely interaction adjustment, social adjustment, and living environment contribute to non-technical adjustment in the general dimension. The interaction adjustment aspect, namely communication, cultural adaptation, and socializing with local society need to be considered because expatriates are unable to adjust with those aspects overseas.

With regard to general adjustment, those elements associated with health facilities, banking, and recreational and entertainment need to be given serious attention. However, expatriates do not face any problems and they can adjust to the conditions and the living condition. Housing provided by their companies also affects this outcome. Therefore, three factors have been identified, namely interaction adjustment, general adjustment, and living environment. These factors have provided the answer to the fulfilment of the first objective of the study. The first objective is about the non-technical adjustment challenges faced by Malaysian expatriates in the construction industry abroad.

The findings have identified several factors that affect the general adjustment of Malaysian expatriates in the Malaysian construction industry. Companies and individuals sent abroad need to realise that there are also nontechnical factors that would influence the successful implementation of projects abroad. The interaction adjustment and general adjustment provide the largest contribution to expatriates' adjustment in their host nation. Other factors such as social relationship with local society, adaptation to the culture of the host nation, and communication are among aspects that companies should give more attention so that expatriate executives can make adjustments to a 
new environment abroad. This study suggests that future study need to focus on family adjustment because this factor also influence expatriate adjustment. Future studies should also pay more attention to qualitative approach so that the real issues confronted by expatriates can be brought up.

\section{REFERENCES}

Anderson, B. A. (2001). Expatriate Management : An Australia Tri-Sector Comparative Study. Thunderbird International Business Review, 43(1), 33 - 52.

Abdul-Aziz, A.-R., \& Wong, S. S. (2010a). Competitive Assets of Malaysian International Contractors. Journal of Financial Management of Property and Construction, 15(2), 176-189.

Abdul-Aziz, A.-R., \& Wong, S. S. (2010b). Exploring the Internationalization of Malaysian Contractors: The International Entrepreneurship Dimension. Construction Management and Economics, 28, 51-61.

Andreason, A. W., \& Kinneer, K. D. (2005). Repatriation Adjustment Problems and the Successful Reintegration of Expatriates and Their Families. Journal of Behavioral and Applied Management, 6(2), 109-126.

Babbie, E. (2010). The Practise of Social Research (12th Edition ed.). Wadsworth: Nelson Education Ltd.

Bhaskar-Shrinivas, P., Harisson, D., Shaffer, M. A., \& Luk, D. M. (2005). Input-Based and Time-Based Models of International Adjustment: Meta-Analytic Evidence and Theoretical Extensions. Academy of Management Journal, Vol. 48(No. 2), 257-281.

Black, J. S. (1988). Work Role Transitions : A Study of American Expatriate Managers in Japan. Journal of International Business Studies, 19(12), 277 - 294.

Black, J. S., \& Mendenhall, M. E. (1991). The U-Curve Adjustment Hypothesis Revisited : A Review and Theoretical Framework. Journal of International Business Studies, 22, 225-247.

Black, J. S., Mendenhall, M., \& Oddou, G. (1991). Towards a Comprehensive Model of International Adjustment : An Integration of Multiple Theoretical Perspectives. Academy of Management Journal, Vol. 16(No. 2), 291317.

Black, J. S., \& Gregersen, H. B. (1999). The Right Way to Manage Expats. Harvard Business Review, 77, 52-63.

Bruning, N. S., \& Wang, X. (2006). Home and Host Country Mentors and Expatriate Adjustment : A Model and Partial Test. Paper presented at the University of Manitoba, Alberta.

Chi, H.-K., \& Chiou, C.-Y. (2007). The Work Adjustment of Taiwanese Expatriates. The Business Review, 8(2), 267-272.

Caligiuri, P., Lazarova, M., \& Zehetbauer, S. (2004). Top Managers' National Diversity and Boundary Spanning : Attitudinal Indicator of a Firm's Internationalization. Journal of Management Psychology, Vol. 23(No. 9), 848859.

Chen, H.-F. (2010). The Relationships of Organizational Justice, Social Exchange, Psychological Contract, and Expatriate Adjustment : An Example of Taiwanese Business Expatriates. The International Journal of Human Resource Management, 21(7), 1090-1107

CIDB (2009), Malaysian Contractors' Achievements in the Global Market, Construction Industry Development Board, Kuala Lumpur. 
Coakes, S. J., Steed, L., \& Dzidic, P. (2006). SPSS version 13.0 for Windows Analysis Without Anguish. Sydney: John Wiley \& Sons Australia.

Collings, D. G., Scullion, H., \& Morley, M. J. (2007). Changing Patterns of Global Staffing in the Multinational Enterprise: Challenges to the Conventional Expatriate Assignment and Emerging Alternatives. Journal of World Business, Vol. 42, 198-213.

CIDB (2008), Malaysian Builders Go Global, Construction Industry Development Board, One-Off Publication, Kuala Lumpur.

CIDB (2009), Malaysian Contractors' Achievements in the Global Market, Construction Industry Development Board, Kuala Lumpur.

CIDB (2016), Annual Report 2015, Construction Industry Development Board, Malaysia, Kuala Lumpur.

Field, A. (2009). Discovering Statistics Using SPSS (Third ed.). London: SAGE Publications Ltd.

Fish, A. (2005). Assisting Cross-border Manager Adjustment: Psycho-cultural and Socio-cultural Interventions. Personnel Review, 24(2), 225-245.

GMAC-GRS (2008). Global Relocation Trends 2008 Survey Report. Illinois: GMAC Global Relocation Services. Gregersen, H. B., \& Black, J. S. (1992). Antecedents to Commitment to a Parent Company and a Foreign Operation. Academy of Management Journal, Vol. 35(No. 1), 65-90.

Huang, T.-J., Shu-Cheng, \& Lawler, J. J. (2005). The Relationship Between Expatriates' Personality Traits and Their Adjustment to International Assignments. The International Journal of Human Resource Management, Vol. 16(No. 9), 1656-1670.

Hurme, F. E. (2007). Competencies for rural nursing practise. Louisiana State University, Louisiana.

Hutchings, K., \& Ratnasari, S. W. (2006). Cross-cultural Non-work Transition Stresses: Domestic Transferees in Indonesia. Cross Cultural Management : An International Journal, Vol. 13(No. 2), 114-131.

Katz, J. P., \& Seiffer, D. M. (1996). It's a Different World out There : Planning of Expatriate Success through Selection, Pre Departure.... Human Resource Planning, 19(2), 32-49.

Lee, L.-Y., \& Vorst, D. V. (2010). The Influence of Social Capital and Social Support on Expatriates' Cultural Adjustment: An Empirical Validation in Taiwan. International Journal of Management, 27(No. 3), 628-649.

Lewis, K. G. (1997). Breakdown - A Psychology Contract for Expatriates. European Business Review, Vol. 97(No. $6)$.

Lorio, C. K. D. (2005). Measurement in Health Behaviour - Methods For Research and Evaluation. San Francisco: Jossey-Bass.

MacKenzie, S. B., P.M. Podsakoff and N.P. Podsakoff. 2011. Construct measurement and validation procedures in MIS and behavioural research: Integrating new and existing techniques. MIS Quarterly, 35 (2): 293224.McGingley, J. (2008). Expatriate Adjustment Within A Social Context : Examination of Sample in Russia. Journal of Social, Evolutionary and Cultural Psychology, Vol. 2(No. 2), 56-68.

Neuman, W. L. (2006). Social Research Methods - Qualitative and Quantitative Approaches (6th ed.). Boston: Pearson Education Inc.

Oberg, K. (1960). Culture Shock: Adjustment to New Cultural Environments. Practical Anthropologist, Vol. 7, 177 182. 
Okpara, J. O., \& Kabongo, J. D. (2011). Cross-Cultural Training and Expatriates Adjustment: A Study of Western Expatriates in Nigeria. Journal of World Business, 46, 22-30.

Osman-Gani, A. A. M., \& Akmal, S. H. (2008). Repatriation Readjustment of International Managers; An Empirical Analysis of HRD Interventions. Career Development International, Vol. 13(No. 5), 456-475.

Piaw, C. Y. (2006). Kaedah dan Statistik Penyelidikan Kaedah Penyelidikan- Buku 1. Kuala Lumpur: Mc. Graw Hill (Malaysia) Sdn. Bhd.

Piaw, C. Y. (2009). Statistik Penyelidikan Lanjutan : Ujian Regresi, Analisis Faktor dan Analisis Sem- Buku 5. Kuala Lumpur: Mc. Graw Hill (Malaysia) Sdn. Bhd.

Paik, Y., Segaud, B., \& Malinowski, C. (2002). How to Improve Repatriation Management - Are motivations and expectations congruent between the company and expatriates. International Journal of Manpower, 23(No. 7), 635-648.

Pamich, M. d. G. H. O. d. (2007). Cross-Cultural Adjustment and The Expatriate Spouse : A Case Study. Capella University, USA.

Pires, G., Stanton, J., \& Ostenfeld, S. (2006). Improving Expatriate Adjustments and Effectiveness in Ethnically Diverse Countries: Marketing Insights. Cross Cultural Management : An International Journal, Vol. 13(No. 2), 156-170.

Roshana, T., dan Ahnuar, E.M (2006). Analysis of Efficiency and Effectiveness Measures of Construction Project Success in Malaysia. International Conference in Built Environment - iCiBE 2006. Kuala Lumpur 13-15 Jun. Salkind, N. J. (2006). Exploring Research (6 $6^{\text {th }}$ ed.). New Jersey: Pearson Education, Inc.

Selmer, J. (2007). which Is Easier, Adjusting to a Similar or to a Dissimilar Culture. Cross Cultural Management, Vol. 7(2), 185-201.

Selmer, J., \& Leung, A. S. M. (2007). Symptom and Problem Focused Coping Strategies of Business Women Expatriates and Their Socio-cultural Adjustment in Hong Kong. Women In Management Review, Vol. 22(No. 7), 588-605.

Sekaran, U. (2006). Research Method for Business (4th ed.). New Delhi: John Wiley \& Sons, Inc.

Shaffer, M. A., Harrison, D. A., Gregersen, H., Black, J. S., \& Ferzandi, L. A. (2006). You Can Take It With You: Individual Differences and Expatriate Effectiveness. Journal Of Applied Psychology, Vol. 91(No. 1), 109-125.

Shay, J. P., \& Baack, S. (2006). An Empirical Investigation of the Relationships Between Modes and Degree of Expatriate Adjustment and Multiple Measures of Performance. International Journal of Cross Cultural Management, 6(3), 275-294.

Shin, S. J., Morgeson, F. P., \& Campion, M. A. (2007). What Do You Depends On Where Your Are : Understanding How Domestic and Expatriate Work Requirements Depend Upon The Cultural Context. Journal of International Business Studies, Vol. 38(No. 1), 64-84

Suutari, V., \& Riusala, K. (2000). Operating in 'Economics in Transition’ - Adjustment and Management Issues Faced by Finnish Expatriate Managers in CEE. 87-107

Tahir, A. H. M., \& Ismail, M. (2007). Cross-Cultural Challenges and Adjustments of Expatriates: A Case Study in Malaysia. Turkish Journal of International Relations, Vol. 6(No. 3\&4), 72-99. 
Takeuchi, R., David, P. L., Sophia, V. M., \& Seokhwa, Y. (2007). Nonlinear influences of stressors on general adjustment: the case of Japanese expatriates and their spouses. Journal of International Business Studies, 38(6), 928-943.

Tucker, M. F., Bonial, R., \& Lahti, K. (2004). The Definition, Measurement and Prediction of Intercultural Adjustment and Job Performance Among Corporate Expatriates. International Journal of Intercultural Relations, 28, 221-251.

Toh, S. M. (2003). Host Country Nationals to the Rescue: A Social Categorization Approach to Expatriate Adjustment. Texas A\&M University, Texas.

Webb, A., \& Wright, P. C. (1996). The Expatriate Experience: Implications for Career Success. Career Development International, Vol. 1(No. 5), 38-44.

Yamazaki, Y. (2010). A fit between skills and demands among Japanese expatriates in USA. Management International Review, 50, 81-108.

Yang, N. (2007). A Cross-cultural Contextual Model of Work-Family Interfaces in Managing International Assignments. Journal of International Business Research, Vol. 6(No. 1), 1-10.

Zakaria, M. Z. (2011). Entry Strategies for Malaysian Construction Related Companies Going Abroad. Kertas dibentangkan pada National Seminar in Built Environment (NSiBE 2011). Kuala Lumpur. 